and Mr. Morison has recently told me that with regard to this particular class of cases he has largely given up his former practice of operating upon them.

A few words about the posture which a patient with suppurative peritonitis should be made to assume. For a long time, as I have already said, I have been in the habit of raising the shoulders of my patients so that fluid in the peritoneal cavity may gravitate towards the pelvis where it can be most easily and safely dealt with. Murphy carries this practice much further and according to Gibbon and Fowler he "has been so much impressed with the advantage of the sitting posture that he now has cases of peritonitis brought to the hospital in the ambulance, anæsthetised, placed on the table, and operated upon in this position." feel sure that Murphy is entirely right and I wish that I could persuade all those who send cases of peritonitis to the Royal Free Hospital to adopt the same precautions.

And now, in conclusion, let me add a few words about that most fruitful source of peritonitis, I mean, of course, acute appendicitis. It may seem to you an extraordinary thing for me to say, but I say it with deliberation and with a profound conviction of its truth, that the very high gross mortality in acute appendicitis which undoubtedly exists in this country (and in other countries as well) is largely due to the fasbion of indiscriminate, excessive, and injudicious operating which not long ago was at its height but which, I venture to think and hope, is now showing signs of subsiding. Appendicitis may or may not be more common than it used to be. Personally I do not think it is, although no one can deny that it is more often diagnosed and I have no doubt that deaths from it are much more common than they used to be. It is not unusual to bear it stated that modern operations for appendicitis have resulted in a great saving of life. I believe that, on the whole, the exact converse is the case. If we were all to go back to the old treatment of appendicitis that was in vogue 25 years ago, and that is still in vogue in many parts of the country, there would be a lesser mortality from appendicitis than is the case at present. This is a very different thing from condemning all operations for acute appendicitis, which $\mathrm{I}$ am far from doing. Nor do I wish to detract from the excellent work that is done by many surgeons of large experience who advocate, and perform, frequent operations for appendicitis and publish very often brilliant results. I am thinking rather of the far larger number of operations performed by those who do not publish their results, performed by those who do not discriminate sufficiently between the cases that should be operated upon and those that should not be operated upon. It is the doctrine of "Here is a septic focus, let us take it out now at all costs," that, in my opinion, does so much harm. It is for more discrimination in the choice of an operation, in the kind of operation, in the stage at which it should be performed, that I would venture to plead.

\section{ACUTE YELLOW ATROPHY OF THE LIVER FOLLOWING OPERATION FOR INTESTINAL OBSTRUCTION.}

\section{BY C. E. CAMPBELL-HORSFALL, M.B., CH.B. VICT.}

ALTHOUGH from time to time cases of acute yellow atrophy are placed on record, yet it remains one of the rarest diseases met with and its causation as inexplicable as ever. But cases following operations are rarer still and with but one exception have all ended fatally. Perhaps before discussing the case which is the subject of this paper it would be well briefly to review the general features of acute yellow atrophy. Osler defines it as jaundice associated with marked cerebral symptoms and characterised anatomically by extensive necrosis of the liver cells with reduction in volume of the organ.

Etiology-This is one of the rarest diseases. There are not more than 300 cases on record. It generally occurs between the ages of 20 and 30 years, but cases have occurred in quite young children and even in infants. It is more common in women than in men and seems to have a remarkable connexion with pregnancy. It has followed fright or profound mental emotion and is sometimes secondary to other ailments-typhoid fever, sepsis, syphilis, gonorrhoea, and phosphorus, antimony, and arsenic poisoning. Although the symptoms produced by phosphorus poisoning are very similar to those of acute yellow atrophy the two conditions are not identical.

Morbid anatomy.-The liver is greatly reduced in size, looks thin and flattened, and sometimes does not reach more than one-half or even one-third of its normal weight. It is flabby and its capsule is wrinkled. On section the colouring is mottled, there being red and yellow areas of softened liver tissue. The organ may cut with considerable firmness. Microscopically the liver cells are seen in all stages of necrosis and in spots appear to have undergone complete destruction. The bile ducts and gall-bladder are empty. Hunter considers that it is a toxæmic catarrh of the finer bile ducts, similar to that which is produced after poisoning by toluylene diamin or phosphorus.

Symptoms.-Commences usually as a gastro-duodenal catarrh and at first the jaundice is thought to be of simple nature. This generally lasts a few days and then severe symptoms set in, headache, delirium, trembling of the muscles, and in some instances convulsions. Vomiting is a constant symptom and blood may be brought up. Hæmorrhages occur into the skin or from the mucous surfaces. Pregnant women may abort. With development of head symptoms jaundice usually increases, coma sets in, and gradually deepens until death. The temperature is variable, sometimes afebrile and in some cases marked pyrexia occurs. Usually the temperature rises just before death to $105^{\circ}$ or $107^{\circ} \mathrm{F}$. The pulse is usually rapid and the tongue is coated and dry. The individual enters into a typhoid state. The urine is bile-stained and contains tube casts. Leucin and tyrosin crystals are not constantly present. The stools are clay coloured from the absence of bile. Cases are almost invariably fatal, there being but few instances of recovery. Nineteen recoveries have been collected by Weising and Ballin. No known remedies have any effect on the course of the disease.

As a sequel to operations Max Ballin has collected ten cases from the literature, a table of which I append below, including the one that came under my own observation. All of these cases, with the exception of Ballin's own case, died.

The following are the notes of the case under my care. On the evening of May 31st, 1904, I was called to see the patient, a young married woman. She complained of severe pain in the lower part of her body and had vomited several times. She had not been feeling well for some time, and two days before I saw her she had had a slight shivering fit. When I saw her she looked anxious and was in evident distress. She had a pulse of 100 and her temperature was $100.5^{\circ} \mathrm{F}$. On further examination I found great tenderness over the abdomen in the lower part, most marked in the left iliac region. No tumour could be felt and there was no marked dulness. The abdomen moved readily with respiration. I elicited the follow. ing further facts. She had been perfectly regular until her last period, which occurred a fortnight previously to the present attack, when she only lost a small quantity of blood, and this not until six weeks after her previous period. She had been very much troubled with constipation which had latterly become much worse. She also suffered from intense dysmenorrboea, being utterly prostrated during the menstrual flow. A vaginal examination revealed marked fixation of the uterus, but otherwise it was negative. The rectum was empty. The patient was kept in bed and a small dose of calomel was administered. On the next morning there had been a slight watery action of the bowels. The temperature was $99^{\circ}$, the pulse was 100 , the pain was more severe, and the vomiting continued, there being nothing distinctive about the vomit. I saw the patient later in the day, when her condition had not improved. A definite mass could be now felt below and to the left of the umbilicus. Vomiting continued, though not fæcal, and the bowels refused to act. There was no marked distension of the abdomen and no visible peristalsis was present. The pulse was still rapid but the temperature was normal. As the symptoms pointed to intestinal obstruction I decided to operate.

The patient was removed to a nursing home, and on the afternoon of the same day chloroform was administered and the abdomen was opened in the middle line below the umbilicus. On opening the peritoneal cavity a little serous fluid escaped. There were marked signs of an old peritonitis, the pelvic viscera being matted together. The cæcum had been dragged over and was fixed on the left side of the abdomen together with the appendix, which was firmly adherent to the cæcum in its entire continuity. The appendix 
Table grving Details of 11 Oases of Acute Yellow Atrophy of the Liver.

\begin{tabular}{|c|c|c|c|c|c|c|c|c|c|c|}
\hline No. & Author. & Sex. & $\begin{array}{l}\text { Years } \\
\text { of } \\
\text { age. }\end{array}$ & $\begin{array}{c}\text { Predis- } \\
\text { position. }\end{array}$ & Anæsthetic. & $\begin{array}{l}\text { Operation } \\
\text { performed. }\end{array}$ & $\begin{array}{c}\text { Onset } \\
\text { of } \\
\text { Icterus. }\end{array}$ & Symptoms. & Result. & Necropsy. \\
\hline 1 & Bastianelli. & ? & $?$ & $?$ & Chloroform. & $?$ & $?$ & $\begin{array}{l}\text { Icterus, vomiting, } \\
\text { delirium. }\end{array}$ & $\begin{array}{l}\text { Died } \\
\text { between } \\
\text { second } \\
\text { and tenth } \\
\text { day. }\end{array}$ & $\begin{array}{l}\text { Fatty degeneration of } \\
\text { heart; nephritis ; } \\
\text { punctiform hæmor- } \\
\text { rhages. }\end{array}$ \\
\hline 2 & $"$ & $?$ & $?$ & $?$ & ", & $?$ & $?$ & ", & ", & $"$, \\
\hline 3 & $"$ & $?$ & $?$ & $?$ & ", & $?$ & $?$ & , & ", & $"$ \\
\hline 4 & Bandler. & M. & 42 & Alcohol. & $\begin{array}{l}\text { Chloroform, } \\
80 \text { grammes. }\end{array}$ & $\begin{array}{l}\text { Herniotomy, with } \\
\text { resection of ad- } \\
\text { herent omentum. }\end{array}$ & $\begin{array}{c}1 \text { to } 2 \\
\text { days. }\end{array}$ & $\begin{array}{l}\text { Icterus, delirium, } \\
\text { coma; tempera- } \\
\text { ture } 40^{\circ} \mathrm{C} \text {. }\end{array}$ & $\begin{array}{l}\text { Died } \\
\text { fourth } \\
\text { day. }\end{array}$ & $\begin{array}{l}\text { Acute yellow atrophy } \\
\text { of liver; icterus } \\
\text { universalis ; multi- } \\
\text { ple hæmorrhage ; ne- } \\
\text { phritis. }\end{array}$ \\
\hline 5 & Stocker. & $\mathbf{F}$. & $?$ & $?$ & $?$ & $\begin{array}{l}\text { Ovarian cyst with } \\
\text { torsion and } \\
\text { necrosis of } \\
\text { pedicle. }\end{array}$ & $?$ & $?$ & Died. & $\begin{array}{l}\text { Ackte yellow } \\
\text { atrophy. }\end{array}$ \\
\hline 6 & $\begin{array}{l}\text { Erlach } \\
\text { ported } \\
\text { Bandler). }\end{array}$ & F. & $?$ & $\begin{array}{l}\text { Catarrhal } \\
\text { icterus. }\end{array}$ & $\begin{array}{l}\text { Billroth } \\
\text { mixture. }\end{array}$ & $\begin{array}{l}\text { Extirpation of } \\
\text { uterus with } \\
\text { morcellement of } \\
\text { fibroma. }\end{array}$ & $?$ & Icterus, delirium. & Died. & $\begin{array}{l}\text { Atrophica hepatis } \\
\text { acutio rubra et flava. }\end{array}$ \\
\hline 7 & Mintz. & M. & 40 & Alcohol. & ? & $\begin{array}{l}\text { Appendicitis with } \\
\text { infection. }\end{array}$ & 1 day. & $\begin{array}{l}\text { Icterus, hæmat- } \\
\text { emesis, convul- } \\
\text { sions, fever. }\end{array}$ & $\begin{array}{c}\text { Died sixth } \\
\text { day. }\end{array}$ & $\begin{array}{l}\text { Fatty degeneration of } \\
\text { heart; parenchyma- } \\
\text { tous nephritis; acute } \\
\text { vellow atrophy of } \\
\text { liver; erosions in } \\
\text { duodenum and } \\
\text { stomach. }\end{array}$ \\
\hline 8 & Marten. & F. & 34 & $\begin{array}{l}\text { Insanity: } \\
\text { indiges- } \\
\text { tion. }\end{array}$ & $\begin{array}{l}70 \text { c.c. chloro- } \\
\text { form, } 40 \\
\text { minutes. }\end{array}$ & $\begin{array}{l}\text { Extraction of } 14 \\
\text { teeth; s u p- } \\
\text { purating necrosis } \\
\text { of jaw. }\end{array}$ & 1 day. & $\begin{array}{l}\text { Icterus, vomiting, } \\
\text { albumin casts in } \\
\text { urine, delirium, } \\
\text { yelling, coma. }\end{array}$ & $\begin{array}{l}\text { Died fifth } \\
\text { day. }\end{array}$ & $\begin{array}{l}\text { Fatty degeneration } \\
\text { of hear and } \\
\text { kidneys; acute } \\
\text { fatty degeneration } \\
\text { of liver. }\end{array}$ \\
\hline 9 & Cohn. & F. & 21 & Alcohol. & Chloroform. & $\begin{array}{l}\text { Salpingo-ovar- } \\
\text { ectomy for pus } \\
\text { tubes. }\end{array}$ & 2 days. & $\begin{array}{l}\text { Icterus, fits of } \\
\text { yelling, de- } \\
\text { liriu m, albu- } \\
\text { minuria. }\end{array}$ & $\begin{array}{l}\text { Died fifth } \\
\text { day. }\end{array}$ & $\begin{array}{l}\text { Cloudy swelling of } \\
\text { heart, liver, and } \\
\text { kidneys ; icteric } \\
\text { meningitis. }\end{array}$ \\
\hline 10 & Ballin. & M. & 20 & Lead. & $"$ & $\begin{array}{l}\text { A ppendicectomy } \\
\text { in inflammatory } \\
\text { stage; adhe- } \\
\text { sions. }\end{array}$ & 2 days. & $\begin{array}{l}\text { Icterus, delirium, } \\
\text { bloody vomit, } \\
\text { a lbum in uria, } \\
\text { leucin and } \\
\text { tyrosin in urine. }\end{array}$ & Recovery. & - \\
\hline 11 & $\begin{array}{l}\text { Campbell } \\
\text { Horsfall }\end{array}$ & $\mathrm{F}$. & 28 & None. & " & $\begin{array}{l}\text { Intestinal ob- } \\
\text { struction due to } \\
\text { adhesions. }\end{array}$ & 1 day. & $\begin{array}{l}\text { Icterus, convul- } \\
\text { sions, vomiting, } \\
\text { coma. }\end{array}$ & $\begin{array}{c}\text { Died fourth } \\
\text { day. }\end{array}$ & $\begin{array}{l}\text { Acute yellow atrophy } \\
\text { of liver. }\end{array}$ \\
\hline
\end{tabular}

was quite healthy. On separating some adhesions a definite mass of about the size of a small orange could be felt on the left side of the abdomen. With great difficulty, owing to the many adhesions, the mass was brought into view and was found to consist of a loop of small intestine firmly constricted at its base by adhesions and tense from accumulated contents. The adhesions were divided and the mass immediately subsided. The intestinal wall had not suffered much damage and so was returned and the abdomen was closed in the usual way with the exception of a small wick of gauze for drainage. The patient stood the operation well and when seen the same night was comparatively comfortable with the exception of vomiting which was considered to be due to the anæsthetic. The vomiting continued the next day and the patient was very restless. Flatus had been passed freely and the temperature and pulse were normal. In the evening I noticed her conjunctivæ were icteric but I did not think it more than the ordinary simple janndice sometimes occurring after an anæsthetic.

On the following morning the patient still continued very restless and the jaundice was now general. Vomiting continued, at first bilious but gradually becoming darker as though mixed with altered blood. The urine was bile stained. The wound was dressed and the gavze wick was removed, everything appearing satisfactory. There was no distension of the abdomen. As the vomiting continued the stomach was washed out and five grains of calomel, followed by one ounce of white mixture, were given by the mouth. Later there was a small action of the bowels and flatus passed freely. The jaundice gradually deepened, the patient became very drowsy, and the skin was dry and pungent, the face being a dusky red in comparison with the yellowishness of the rest of the body. There were convulsive movements of the limbs on both sides, followed by well-marked muscular rigidity. From this she gradually passed into a condition of coma vigil, was totally unconscions, had deep, stertorous breathing, and fixed, staring eyes with widely dilated pupils.
The urine became diminished and was passed involuntarily. On percussing the liver the dulness anteriorly was markedly decreased. The vomiting became less as the patient's condition grew worse. The urine was examined for leucin and tyrosin crystals with a negative result, but albumin and bile pigments were present. A diagnosis of acute yellow atrophy was made. Venesection was at once performed and several pints of normal saline solution were injected into the median cephalic vein of the left side, but all to no purpose. The temperature gradually rose to $105^{\circ}$ and death took place early the next morning.

I obtained permission from the relatives to make a partial post-mortem examination. I removed the liver after first ascertaining that there was no obstruction to the common duct. The liver was much reduced in size and its capsule was shrunken. The gall-bladder was filled with thick bile. A section of the liver showed areas of red softening, the surrounding parts being yellowish. The liver tissue was very friable. The ducts macroscopically were healthy. I re opened the operation wound and found everything healthy, there being no evidence of suppuration anywhere. A portion of the liver was sent to the pathological department of University College, Bristol, and was reported on as follows : "The specimen was very soft and friable. There is present a great degeneration of the liver substance, with deposition of pigment. The amount of newly formed fibrous tissue is small, thus indicating great acuteness of the disease. The appearances presented are those usually seen in acute yellow atrophy."

The notes of the above case are of more than usual interest, rartly because of the extreme rarity of the disease and more so because of the fact that there are now on record 11 cases following an operation in which an anæsthetic has been given, and as such should be reckoned as a possible complication following operation. Modern text-books nearly all omit to mention it.

On referring to the table it will be seen that in all but 
three cases the anæsthetic used has been chloroform or some preparation of chloroform, so naturally the question arises, What influence does chloroform play in the cause of this condition? There is no record of any case where the condition has followed the administration of ether and from this fact alone it is highly suggestive that chloroform plays some part. Mintz, because he found the bacillus coli in the liver of his case, suggests a bacterial cause of the condition. That the colon bacillus should find its way into the liver in these cases is not to be wondered at, and its presence hardly warrants the assumption that it plays any active part in the condition. To my mind it is only a probable coincidence. The toxic theory of the disease is more tenable and helps to explain in some measure the cases following on chloroform administration. It is quite conceivable that the primary toxic agent is the result of faulty metabolism, and in regard to the cases under discussion the presence of chloroform is the crowning factor in the causation of the disease, by which I mean the chloroform intensifies in some way the already active poison.

There are many points of similarity between the symptoms and signs after death from chloroform and those of acute yellow atrophy. Chloroform when taken internally in a poisonous dose produces vomiting, coma, jaundice, and dilatation of the pupils. The post-mortem findings show degenerative changes in the liver cells, heart, and kidneys very similar to those found in acute yellow atrophy. That these lesions are caused by chloroform are amply proved by the experiments of Nothnagel, Toth, Unger, and others on animals. On the other hand, that chloroform is not an essential factor in the disease is proved by the greater majority of the cases of acute yellow atrophy which have occurred where there has been no chloroform used. It is a matter of conjecture whether the symptoms of acute yellow atrophy are part of a general toxæmia or whether they are the outcome of the active changes taking place in the liver. It ssems that whatever the source of the poison, its chief effects are exerted upon the liver, heart, kidneys, and brain. That it is a severe cerebral poison is shown by the vomiting, delirium, muscular tremors, dilatation of the pupils, \&c. In regard to the treatment much remains to be done. With the exception of one case in the table all the cases ended fatally. In my own case, although similar treatment as that used by Ballin was at once made on realising the condition, yet it was without avail. That cases do recover is quite conceivable considering that in many cases the liver tissue is shown by the microscope to be undergoing repair and it is quite feasible that the individual may be able to overcome the severe toxæmia.

Whatever the cause of this terribly fatal condition is, at present most is theory and conjecture without very much direct proof. Personally the most plausible theory to my mind is that it is a toxæmia arising from the gastro-intestinal tract, and should I ever have a similar case to deal with my treatment, in addition to diluting the poison by venesection and transfusion, would be by the exhibition of intestinal antiseptics.

Cheltenham.

\section{INTUSSUSCEPTION CAUSED BY AN IN- VERTED MECKEL'S DIVERTICULUM ; EXCISION AND END.TO-END ANASTOMOSIS.}

WITH REMARKS ON END-TO-END ANASTOMOSIS.

By LeONARD A. BIDWELL, F.R.O.S. ENG., SURGEON TO WEST LONDON HOSPITAL, ETC.

A HEALTHY boy, aged three and a half years, had a severe hæmorrhage from the bowel in June, 1906. He was examined carefully per rectum by his medical attendant but nothing abnormal could be detected. The boy seemed to recover completely and remained well till about the middle of October when he began to have attacks of severe abdominal pain followed by vomiting; these came on at intervals of one week, commencing as soon as the child got up in the morning and passing off within an hour or two, after which he remained quite well till the next weekly attack. On Nov. 21st he had one of these attacks, which, however, did not pass off and was accompanied first by vomiting and then by persistent retching. He was seen by Major E. M. Pilcher, R.A.M.C., who examined him, and finding a hard tumour in the right lumbar and hypochondriac regions diagnosed an intussusception, and recommended an operation. I saw the boy at 5 P.M., six hours after the commencement of the attack. The child was evidently in considerable pain, his legs were drawn up and his abdomen was rigid; there was no elevation of temperature, but the pulse-rate was 140 . He had passed neither motion, blood, nor mucus, although a large enema had been given. The tongue was slightly dry and retching was constant. A well-marked tumour was felt in the right lumbar and umbilical regions but nothing abnormal was detected on rectal examination. The diagnosis of intussusception was fairly certain and I decided on immediate operation.

The patient being under chloroform I opened the abdomen between the outer fibres of the right rectus muscle and found an intussusception which involved the large intestine as far as the middle of the transverse colon. The intussusception was brought out of the wound and was reduced with little difficulty. It was then found that the invagination had commenced in the ileum about six inches from the cæcum. The bowel after reduction appeared black and oedematous but its peritoneal coat seemed all right No polypus or other cause for the intussusception conld be found. It was not thought desirable or necessary to shorten the mesentery or to fix the bowel to the parietes, so the abdominal wound was closed. The patient made a rapid recovery but one week after the operation he bad a slight attack of pain rather resembling those which he had before. On Dec. 21st, when he was allowed to sit up and move about in bed, he had another severe attack of pain, and Major Pilcher discovered a well-defined tumour which, however, differed rather from the original one ; it was more curved and nearer to the umbilicus and could be moved easily when the abdominal walls were relaxed. The child was in severe pain and was constantly retching. I saw the child a few hours later and reopened the abdomen. The intussusception was brought out of the abdomen and was found to involve the small intestine alone; it was discoloured and measured about four inches. I attempted to reduce the intussusception by kneading and squeezing but without success, so as time was of every importance in so young an infant I did not waste any time in prolonged attempts but decided to excise the mass. The bowel was divided transversely one inch above and one inch below the intussusception, the mesentery was ligatured, and the whole intussusception removed. The cut ends of the bowel were united in the manner to be presently described. The child suffered very little shock and made an uninterrupted recovery. He has had no further trouble. The portion of the gut removed measured eight and a half inches and at the apex of the intussusception was found an inverted and clematous Meckel's diverticulum. This quite explained the impossibility of reduction.

There are several points of interest in this case; first, the history of weekly attacks of abdominal pain lasting an hour or two and followed by complete recovery; these I believe to have been transitory intussusceptions, as I am sure that a number of cases of slight intussusception are relieved by nature. I have several times been asked to see children supposed to be suffering from intussusception and I have been given a history of a well-defined lump, together with vomiting and the passage of blood and mucus, but when I have examined the case I have detected nothing abnormal. I always consider such cases as cures of intussusception by spontaneous reduction. The second point of interest in this case is that neither blood nor mucus was passed per rectum and that obstruction was complete at once; these points are probably due to the position of the intussusception in the small intestine. The third point was that an inverted Meckel's diverticulum was the cause of the invagination; it is a somewhat unusual occurrence and explains the fact that the intussusception commenced in the small intestine. In connexion with the existence of the Meckel's diverticulum it is interesting to state that the child was born with an umbilical hernia which persisted in spite of pads and appliances and for which I did a radical cure when the child was one year old. A somewhat similar case has recently been reported by $\mathrm{R}$. 0 . Coffey in the "Annals of Surgery"; it was that of a boy, aged seven years, who presented a similar history of attacks of abdominal pain commencing with melæna and occurring at intervals of one week. In this case the intussusception was entirely ileo-colic and at the operation ( 36 hours after the commencement of the attack) it was found to be gangrenous. 